\title{
34. From scooter to boat: innovations in electric transport in cities of Southeast Asia $^{1}$
}

Pippo Ranci

\section{FIGHT LOCAL POLLUTION AND CONGESTION AND YOU WILL REDUCE GHG EMISSIONS}

It is a lucky circumstance that greenhouse gas (GHG) emissions go largely together with local pollution. While it is difficult to convince people to accept a burden on their life today only because this will improve the world in the future, it is much easier to gather support for innovations that produce an immediate reduction of pollution and congestion in densely populated cities. Large cities in Southeast Asia provide encouraging examples of such developments.

Congestion and pollution from road traffic represent an urgent issue in Southeast Asia and China. India and China alone account for 37 out of the world's 50 most polluted cities. While in developed countries personal transportation is dominated by cars, in the developing world two-wheelers account for the majority of vehicles on the road, and three-wheelers are also widely diffused. This is why electrification of these light vehicles is a priority to reduce congestion and pollution. It will also provide powerful advances towards a reduction of GHG emissions.

One key to progress is a fast diffusion of information and communication technologies. New apps and new systems can reduce congestion through diffusion of vehicle sharing. This provides a benefit, even if traditional fossil fuel-powered vehicles remain. On the other side, diffusion of electric vehicles can radically reduce emissions, even if the traditional model of individual ownership and use is maintained.

The combination of a technology-based sharing system and diffusion of e-vehicles can provide a really effective and fast change. Innovative electric urban transport services are spreading fast in Southeast Asian cities and promise to change the habits and preferences of millions of people, improve 
their lives, foster economic development, and contribute to mitigating climate change.

I shall summarily illustrate a limited number of case histories in the areas of light vehicles, cars, and boats, with a paragraph focusing on the alternative charging systems and the role of integrated systems.

\section{TRANSFORMATION OF THE RICKSHAW AND OTHER LIGHT VEHICLES}

We start from the lightest of all vehicles - the push scooter that has long been a toy for children. Now endowed with a small battery-powered electric engine, it has become a short-distance individual vehicle that, well before coming back into fashion in the West, has started contributing to the revolution in Southeast Asian cities described here. The Neuron Mobility company is offering e-push scooters in Singapore, Bangkok and Chiang Mai (Thailand), Cyberjaya (Malaysia), and Brisbane (Australia). Singapore-based GrabWheels also operates this service in university campuses in Jakarta (Indonesia): you can share the scooter and use it at will. You can also take it home, accept a part-time job as a GrabFood delivery rider, and turn your expenditure into an income.

Our next step is the electric bicycle. E-bikes are spreading both as individually owned vehicles and as a sharing service. Mobycy operates e-scooter- and e-bike-sharing services in five Indian cities.

Third step, the rickshaw. Sasiranga De Silva, a 33-year-old engineer and university lecturer, set about finding the most effective way of tackling the harmful gases and noise that make life a misery for commuters in his native city of Colombo, Sri Lanka. He decided to focus on tuk tuks, the three-wheel auto rickshaws used by millions of people across the world, particularly in Asia and Africa. There are around 1 million tuk tuks in Sri Lanka, providing essential, affordable transport for many of the country's 21 million people. De Silva developed an affordable conversion kit to allow tuk tuks to run on electric power. His innovation won a US\$20 000 grant from the UN Environment Programme (UNEP, 2018) as part of the Asia Pacific Low Carbon Lifestyles Challenge. De Silva, who will also receive business and marketing training as part of his prize, says his conversion kit, based around a rechargeable lithium-ion battery, will reduce noxious emissions and also save tuk tuk drivers money over time. Presently, they generally pay US\$4000 to buy their vehicle. The converter kit could be priced at US\$2000 and save drivers US\$1000 a year (UNEP, 2019).

De Silva's conversion kit may be important, yet e-rickshaws have existed for a long time in Southeast Asia. In Nepal, an e-rickshaw system called SAFA Tempo was introduced in 1996, as a replication of e-tuk tuks already operating in India and in Sri Lanka at the time. Today, 700 SAFA Tempos run on the 
bumpy streets of Kathmandu, generally run by women, providing passenger services: one of the many projects managed by the US non-profit Winrock International.

In India, electric rickshaws are operated in 71 cities, and their diffusion is increasing. In 2015, the amended Motor Vehicles Act carried a definition of the e-rickshaw as "special 3 wheeled vehicle of power not exceeding 4000 Watts" and the Government of India's Smart Cities Mission, based on proposals by city governments, included financing for e-rickshaw purchase and deployment in 29 cities and for e-rickshaw charging infrastructure development also in 13 other cities. ${ }^{2}$

\section{ELECTRIC CARS, OWNED OR SHARED}

Ola Cabs is an Indian transportation network company offering services that include peer-to-peer ridesharing, ride service hailing, taxi and food delivery. Founded in 2010, it is now valued higher than $\$ 6$ billion. It is the leader of hail-ride taxis, the Uber model, in India. In 2015, it spun out Ola Electric, an e-mobility system company, with the collaboration of the government, since the country has set a goal to gradually convert the fleet to electric. Ola Electric plans to initially place $10000 \mathrm{e}$-vehicles in one year.

Other car-sharing companies, like Haupcar in Thailand, are introducing e-cars in their fleet. Given the relatively high cost of an e-car, electrification is easier in the sector of car sharing than in the ordinary car market. In Singapore, the BlueSG company was created in 2017 and offers an e-car sharing service in 300-locations.

The business models are many, and they change according to experience and opportunities. The Malaysian company COMOS launched an e-vehicle sharing programme in 2015. As growth came too slow, the company shifted its focus to conventional car rental, then it embarked on an e-bike sharing programme at universities and in green tourism.

\section{THE RECHARGING CHALLENGE AND THE GROWING ROLE OF INTEGRATED SYSTEMS}

Any electric vehicle relies on a battery, and one crucial element of its performance is the capacity of the battery, in terms of driving range, related to its weight and volume, and to its cost. Although two- and three-wheelers have an advantage over cars in terms of size of the battery needed, and they are used within the urban area only, their recharging is an issue.

In general, a large organization is necessary for serving a variety of e-vehicles, and here is where the ingenious inventor is not sufficient. Only a large company will be able to cover the area with a charging network. The 
task has an easy solution in the case of sharing, since pick-up sites may be charging points as well. This is the case of Singapore's car-sharing company BlueSG, and it may become a model for the sharing of e-bikes and other light e-vehicles.

In the general case of owned vehicles, there is a basic alternative. A provider may choose a proprietary method that will not be available to drivers who have preferred a competing brand. Alternatively, open methods may develop and be available to vehicles of different brands: competition will be eased.

Here is where a body representing the public interest, like a local or national administration, plays a crucial role. A public initiative and a clear discipline (including the rights and conditions for individual recharging at home and private recharging sites for large fleets) is a recognized necessity, and government action is present in various countries. It is crucial that this happens at an early time in the development of the service. ${ }^{3}$

A recharging network can be based on plug-in recharging or on battery swapping. Both types have been introduced and are developing. First, with regard to plug-in recharging, India's Ather Energy is offering three models of e-scooter for individual purchase accompanied by access rights to a network of recharging stations, presently being expanded to 30 Indian cities, where the onboard navigator indicates the nearest station, fast service is based on a proprietary method fit for Ather vehicles, and an ordinary socket for charging is also offered to all electric vehicles. Second, with regard to battery swapping, the Taiwanese electric scooter company Gogoro has developed fast-swapping batteries, which can be replaced at gas stations and close to convenient stores. More than 300 stations will open soon, and the autonomy on one charge is about $100 \mathrm{~km}$. However, lack of uniformity may provide the benefits of competition, yet it will also increase costs and possibly slow down diffusion.

While recharging is usually provided by using electricity supplied by the local network, a charging network using solar energy is now offered by ChargeGrid, a spinoff of Magenta Power, a rooftop solar developer based in Mumbai (India) and now growing through an alliance with Hindustan Petroleum Corporation Limited (HPCL), a big Indian oil and gas company. It offers fully automated, unmanned stations, remotely monitored through an advanced system.

In general, the need for easy and performing services is opening the way to integrated companies, offering many services through a proprietary, versatile app. An example of a company built around an app is Bykea, started in 2016 and operating in the main Pakistani cities: Karachi, Lahore and IslamabadRawalpindi. It offers on-demand rides, express parcel services, bills and ticket payments. 


\section{ELECTRIC BOATS}

The city government of Kaohsiung, a city in Southern Taiwan with a 2.8 million population, has introduced hybrid electric ferry boats for passenger services, to reduce pollution. If successful, the initiative will be extended to the rest of the diesel fleet to ease pollution around Taiwan's largest harbour.

An advanced version of the electric ship is the solar-powered ferry, like the one operating between Vaikom and Thavanakkadavu in the Indian state of Kerala. Inaugurated in 2017, it was built by NavAlt Solar \& Electric Boats in Kochi, India. NavAlt is a joint venture firm between Navgathi Marine Design \& Constructions, Alternative Energies (France) and EVE Systems (France). Its cost is 60 percent higher than a diesel-powered boat with the same functional features and safety standards. Considering the fuel savings, the new model has a payback period of less than three years, and it eliminates pollution. Thus, substitution of diesel-fuelled ships looks promising in many densely populated cities built along a river or along the seashore. The sales of electric and hybrid vessels are expected to increase significantly over the next decade, climbing to over US $\$ 20$ billion worldwide by 2027 - according to a report by IDTechEx, a UK-based tech consultancy firm (Gear, 2020).

Innovation is easier where electrification involves few, relatively large, centralized decisions, and yet it can also be targeted to the numerous, small independent operators. A Singapore-based renewables start-up is on a mission to replace polluting diesel-powered boats with solar-charged electric vessels in Southeast Asia, inspired by Swedish furniture retailer IKEA's approach to part distribution and assembly.

Southeast Asia simply could not function without this life-supporting mode of transport. The Philippines is made up of 7641 islands, while 13466 islands make up the Indonesian Archipelago. One of the most important rivers in the world, the Mekong, is home to 60 million people spread across Myanmar, Vietnam, Laos, Cambodia and Thailand who live along its tributaries and depend on the river for food, water and jobs.

Many of the region's boat users are fishermen; one-fifth of the world's fish catch comes from Southeast Asia, and Indonesia, Thailand, Vietnam and the Philippines make the list for the world's top ten fish producers. Another big part of the region's boat fleet is devoted to tourism; popular travel destinations such as Krabi, Phuket, Boracay and Bali use smaller vessels for island-hopping tours.

Heavy, diesel-powered wooden boats are the primary form of transport for navigating the waterways of developing Southeast Asia. Referred to as rua hang yao in Thailand, thuyền gố in Vietnam, bangkas in the Philippines and jukungs in Indonesia, these vessels are typically made of timber from fully 
grown trees and crafted by local boat builders. Motor engines, fuelled by diesel, are then fitted so that the boats can traverse long distances. Increasing boat numbers have sparked concerns over fuel leaks and noise pollution, which harm marine life and affect fisheries and the quality of tourist sites. Responding to this need, renewable energy solutions such as solar-powered boats look promising in Southeast Asia.

Hans van Mameren, a septuagenarian Dutchman who runs Singapore-based renewable energy consultancy Energy Renewed, has an ambitious plan to electrify 1 million diesel boats in Southeast Asia. He spent 50 years in the shipping business before launching his clean energy venture in 2017. Van Mameren's new company will supply the parts for the boats and instructions for how to assemble the kit, but, ultimately, the vessels will be put together by local boat builders who can sell off the completed boats and turn a profit. Currently, Energy Renewed's team of engineers in Singapore is working on a prototype for their electric boat assembly kit, and they plan to go to market by the end of 2020. Two prototypes have been designed, one for a catamaran and another for a longboat.

Describing local boat builders as "craftsmen", van Mameren is confident that locals who use wooden boats can easily translate their traditional boat building skills into the modern composite boat building that is needed for electric boats. His assembly kits will come with an instruction manual in the local language, and he also intends to organize training sessions to familiarize local boat builders with the assembly procedure.

Van Mameren also thinks that his idea, while expensive at the outset, will generate savings over the long term. According to his calculations, Indonesian fishermen in the divers' paradise of Raja Ampat, West Papua, spend about half of their incomes on fuel. So, instead of selling the assembly kit at prices that are beyond the incomes of local boat folk, he intends to work with local dealers to lease his electric boat assembly kits at prices lower than what they would spend on fuel.

Perhaps the biggest appeal of van Mameren's solution is its capacity to double as a rural electrification scheme. If he can secure partners to install solar panels on his customers' homes, he thinks that locals are very likely to embrace his renewable energy solution. Besides creating the boat assembly kit, van Mameren's bigger ambition is to work with solar technology specialists to install solar panels in villages where his electric boats operate. These panels will supply clean energy to charge the boats and also provide electricity for daily consumption - an important bonus for those living off-grid. "Most fishermen load ice blocks from the main ports and ferry them back to their villages to preserve their catch. If they have electricity in their villages, they can power small refrigerating units and preserve their fish there", said van Mameren (Kong, 2019). 


\section{A WARNING AND A TENTATIVE CONCLUSION}

Although most of the information presented above is drawn from official or fully reliable research sources, some use of other websites, apparently reliable, has been made. It is also certain that many other initiatives, not mentioned here, are at least as worth mentioning as the ones described here.

This chapter shows cases of private for-profit or non-profit initiatives and state activities, variously combined, targeted to overcome situations of urban traffic congestion and pollution and reduce damage and suffering of large populations. In so doing they contribute to abating $\mathrm{CO}_{2}$ emissions and mitigating climate change.

Southeast Asia is engaged in a race against time. Other parts of the world are living through similar challenges and may have something to teach and much to learn. Information is precious and collaboration, including freer trade, will be very useful.

\section{NOTES}

1. The author gratefully acknowledges information and analysis provided by Pradyumna Bhagwat of the European University Institute and Salvatore Vinci of IRENA.

2. A description of the diffusion of e-rickshaws in India (including an impressive map, p. 5), and of the promotion of e-rickshaws by the federal government and by many state governments may be found in Shandilya, Saini and Ghorpade (2019).

3. Please refer to note 2 .

\section{REFERENCES}

Gear, L. (2020), "Electric leisure \& sea-going boats and ships 2021-2040", Idtechex. com, accessed 27 August 2020 at https://www.idtechex.com/en/research-report/ electric-leisure-and-sea-going-boats-and-ships-2021-2040/739.

Kong, Y.X. (2019), "An idea to electrify 1 million boats in Southeast Asia - inspired by IKEA", Eco-business.com, 26 August, accessed 18 August 2020 at https://www.eco -business.com/news/an-idea-to-electrify-1-million-boats-in-southeast-asia-inspired -by-ikea/?sw-signup=true.

Shandilya, N., V. Saini and A.R. Ghorpade (2019), Handbook: E-rickshaws Deployment in Indian Cities, New Delhi: ICLEI South Asia.

United Nations Development Programme (UNEP) (2018), "Twelve Asian entrepreneurs awarded for forward-thinking environmental solutions", 25 March [press release], accessed 17 August 2020 at https://www.unenvironment.org/news-and-stories/press -release/twelve-asian-entrepreneurs-awarded-forward-thinking-environmental.

UNEP (2019), "Taming the sputtering tuk tuk: Sri Lankan innovator develops affordable electric conversion kit", accessed 17 August 2020 https:/www.unenvironment.org/ news-and-stories/story/taming-sputtering-tuk-tuk-sri-lankan-innovator-develops -affordable-electric. 